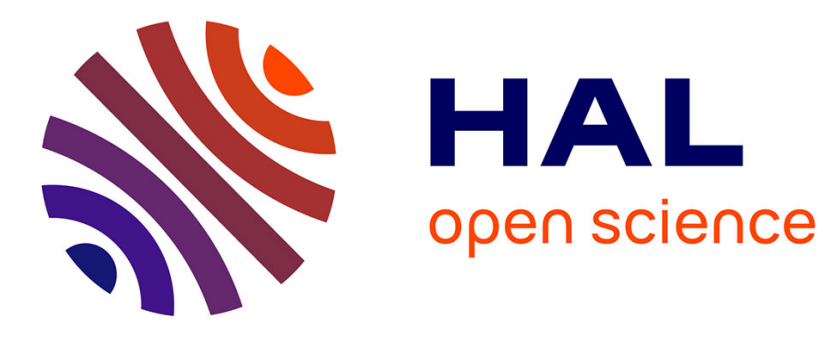

\title{
Integrating via networks: foreigners and others
}

Michael Eve

\section{To cite this version:}

Michael Eve. Integrating via networks: foreigners and others. Ethnic and Racial Studies, 2010, 33 (07), pp.1231-1248. 10.1080/01419871003624084 . hal-00598964

\section{HAL Id: hal-00598964 https://hal.science/hal-00598964}

Submitted on 8 Jun 2011

HAL is a multi-disciplinary open access archive for the deposit and dissemination of scientific research documents, whether they are published or not. The documents may come from teaching and research institutions in France or abroad, or from public or private research centers.
L'archive ouverte pluridisciplinaire HAL, est destinée au dépôt et à la diffusion de documents scientifiques de niveau recherche, publiés ou non, émanant des établissements d'enseignement et de recherche français ou étrangers, des laboratoires publics ou privés. 


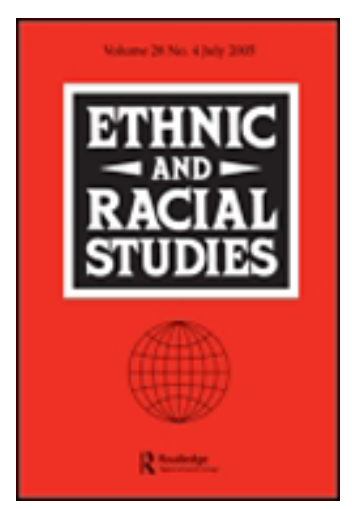

Integrating via networks: foreigners and others

\begin{tabular}{|r|l|}
\hline Journal: & Ethnic and Racial Studies \\
\hline Manuscript ID: & RERS-2009-0157.R1 \\
\hline Manuscript Type: & $\begin{array}{l}\text { Jens Schneider / Maurice Crul THEORISING } \\
\text { INTEGRATION AND ASSIMILATION }\end{array}$ \\
\hline Keywords: & $\begin{array}{l}\text { integration, internal migration, stratification, Italy, Social Mobility, } \\
\text { social networks }\end{array}$ \\
\hline
\end{tabular}

\section{ScholaronE \\ Manuscript Central}




\title{
Integrating via networks: foreigners and others
}

\begin{abstract}
The article analyses some general network mechanisms underlying the formation of social ties in order to argue that it is not only identity, cultural similarity or discrimination which creates clusters of people of the same 'origin' (in, say friendship groups). Widely held assumptions about the logic underlying ethnic segregation are challenged and it is argued that migration itself leads to a reorganization of social networks which can produce marked separation of groups. Evidence is discussed from an Italian case of mass internal migration which has produced long-term ('second generation') effects in terms of stratification and schooling similar to many cases of international migration notwithstanding the absence of citizenship disadvantage and major cultural differences. This seems to illustrate marked network effects on many dimensions of 'integration'.
\end{abstract}

Keywords: integration; social networks; personal relationships; internal migrants; occupational mobility of migrants; migration and stratification.

In the field of migration - in both public and academic debate - reference to integration is ubiquitous (albeit often undefined). In sociology and social science 
more generally, on the other hand (at least since Parsons, and discussion of the 'racial integration' of schools and neighbourhoods in the 1950s and '60s), the concept makes only an occasional appearance. Integration evidently seems a question which concerns those who are in some sense considered (socially, if not legally) 'foreigners'. At the same time, integration is mostly conceived in terms of collective blocs. Thus there is controversy over whether 'young Maghrébins' are 'integrated' into 'French society', 'Asians' in 'British society', the terms being an 'ethnic group' on the one hand and 'society' or 'the nation' on the other. Even though it is widely recognized that it is unrealistic to think of either national cultures or national societies as undifferentiated blocs, much reasoning continues to pose the question in these ethnic and national terms, and to use empirical evidence at this level of aggregation.

\section{Are ethnic groups the most appropriate level of analysis for analysing 'social' integration?}

However, it may be fruitful to think in less 'macro' terms ${ }^{1}$, for all individuals have to make transitions, 'enter' into new groups (a school, a workplace, a family of marriage, a new neighbourhood or village, an association, etc.). Ordinary speech reflects this and some European languages not infrequently use the term integration: so we hear statements like 'I never really managed to integrate into that workplace', or 'he has integrated really well into his new school'. This suggests that it may be fruitful to examine the general logic underlying sociability - the factors influencing the formation of relationships at a local level, from friendships to marriage or relationships with colleagues, the relationships formed after a move to a new town, 
etc. Looking at 'integration' into a new group or ambiance as a 'meso' question of reorganizing one's social network and forming new ties brings out regularities which, I believe, can shed light also on some of the questions traditionally associated with discussion of the integration of immigrants and questions of how social inequalities are generated.

Of course, many studies of integration make reference to personal relations. Questions on the nationality of friends are, for example, a stock item in questionnaires investigating integration, and intermarriage is a widely-used 'measure of integration' (notwithstanding the ambiguities emphasized by Miri Song in this volume). However, personal relations are mostly used as indicators of the 'level of integration' reached, rather than being investigated as objects of investigation with their own dynamics. And the function is usually to measure the level of mixing or segregation between individuals qua representatives of ethnic groups (with foreignness or ethnicity implicitly seen as the cause of the patterns found). Milton Gordon's (1964) classic work on assimilation is still worth analysing in this context, for it makes assumptions which remain widespread in implicit form. Gordon argued that at the level of 'structural assimilation' American social structure was essentially a set of ethnic clubs:

each racial and religious (and to a lesser extent, national origins) group has its own network of cliques, clubs, organizations, and institutions which tend to confine the primary group contact of its members within the ethnic enclave, while interethnic contacts take place in considerable part only at the secondary level of employment and the political and civic processes. (1964, pp.110-11) 
Gordon summarizes much interesting data showing that in post-war America a child of (say) Italian (Jewish, etc.) migrants was rather likely to go to a school and scout group where many others were of Italian (etc.) descent, to attend a 'national parish' church, to live in a neighbourhood with ethnic connotations, to have a high proportion of co-ethnic friends and marry co-ethnics. This continuing separation at the social level (notwithstanding assimilation at the level of language, appearance and external customs) is explained partly in terms of exclusion by WASPs, and partly by the defensive reaction of immigrants and their descendants: according to Gordon migrants and their children felt it more relaxing to be with 'birds of our feather' - especially if they had received rebuffs in attempting to enter white Protestant strongholds. A notion of comfortableness is fundamental to Gordon's notion of how primary relationships form. Gordon sees the personal relations as forming through the ease of communication and the 'sense of peoplehood' among members of the same ethnic group. More precisely, it is with other members of the same 'ethclass' - class fraction of an ethnic group - with which one really identifies and feels 'consciousness of kind':

with these particular members of the human race and no others we can really relax and participate with ease and without strain (ibid., pp.53-4).

In other words, in Gordon's account, it is essentially cultural preference (of migrants descendants and WASPS) which underlies the structuring of personal relations.

However, this is too simple a view of the formation of personal relationships. Even if we assume that individuals invariably prefer cultural similarity (discounting the attractions of the prestigious or the 'different'), it is unrealistic to imagine social ties being independently chosen by individuals solely on this basis. Even in voluntary relationships, individuals do not interact only on the basis of cultural similarity (let 
alone cultural similarity defined on the basis of an ethnic label), for they need to achieve various kinds of objectives. Gordon's actors are purely abstract representatives of ethnic (and class) groups, not people who need allies, want to undertake particular kinds of activities together, feel obliged to repay favours, and who have a limited range of contacts and information. Even in the situation of a country club committee considering an application for membership (which Gordon seems to take as paradigmatic), decisions can be influenced by internal conflicts in the club, the desire to further one's business and political interests, etc. In any case, few relationships are like an application for membership to a country club explicitly concerned with exclusivity and status. Furthermore, even where easy, tail-wagging similarity does exist between members of the same ethclass, this is rarely sufficient to create a durable social tie, for people may get on splendidly when they meet, but then never see each other again.

Few researchers are as explicit as Gordon about social ties being explained by ethnic attraction or rejection, but even today the categorization of data collected pushes the argument in the same direction: here, as elsewhere, much of our thinking is done via the methods and categories of analysis, and what these make visible. Researchers often collect data on social relations of individuals, classified in terms of ethnicity, and then calculate the proportion of ties occurring within an ethnic group or outside it, using this proportion as an indicator of the degree of integration/assimilation. In the absence of more detailed relational data on the contexts in which relationships form - for example on overlaps between extended kin and neighbourhood, or between neighbourhood and school - data ordered on the basis of ethnicity tends to make it appear as if the ethnic identity of the people concerned (rather than, say, the fact of being introduced by a relative, or going to the 
same school) explains the patterns found. The social salience of ethnic and national labels on the one hand, and the prominence of public concern about prejudice and discrimination by natives on the other hand, means that it is easy to attribute causal force to ethnicity itself (Gordon's mechanisms of cultural ease among co-ethnics or rejection by others). The empirically-found density of relationships with co-ethnics thus tends to seem confirmation of the group as a real group, and confirmation of the importance of ethnic identity as determining choices (and, ultimately, the social structure). Ethnic networks appear to be authentically about ethnicity, driven by cognitive mechanisms of identity, categorization, difference. However, other interpretations are possible. In seeking to explain Gordon's data, we might hypothesize that it was precisely the ethnic concentration in one social ambiance from neighbourhoods to churches to scout groups to kinship itself - which leads to the high percentages of intra-ethnic marriages or friendships. Gordon himself notes (1964, p. 204-6) that the very high proportions of Italo-American ties reported in Street Corner Society (Whyte 1943) might be lower in a mixed Italian-Irish neighbourhood. But he does not generalize the point to see that it might be fruitful to focus on mechanisms leading to friendships, marriage, etc., rather than only on numbers of ties which cross ethnic boundaries.

In fact if we focus on the mechanisms underlying the formation of personal ties, we find that one relationship is consistently related to others. The importance of the equivalent of street corners is no less evident in a modern ethnographic classic like Lepoutre's (1997) study of groups of adolescent boys on a housing estate outside Paris - but with opposite results. At least as much as in Cornerville, there was an intensely local basis for the formation of friendships, to the extent that Lepoutre was tempted to talk of a 'staircase patriotism' (many groups in fact originated in 
relationships formed among children who clustered around the bottom of the staircases in the particular block of flats where they lived). But since the residence patterns were different (being determined by admission criteria of the public housing body) Lepoutre's friendship groups nearly all contained mixtures of national origins, blacks, 'Beurs' and poverty-stricken 'de souche' French. In both Whyte's and Lepoutre's contexts, it was probably the social importance of participation in a series of very local activities and conversations which created and maintained the ties, but the results in terms of ethnic homogeneity of friendships were different.

I am not claiming of course that neighbourhoods always create ties of friendship. What I am claiming is that if in a particular situation living on the same staircase is a basis for children to play together (for example) this may have effects on subsequent relationships, and that to understand why ethnic concentrations sometimes form and sometimes do not, we need to know how relationships originate and are maintained.

Studies of how personal relationships form more in general bring out the importance of 'local' relational contexts in a broader sense. Research on how people find their spouses (Bozon and Héran 1989; 2006) or friends (Allan 1989; Bidart 1997) show that it is participation in the same circles and activities which leads to most ties. A relatively small number of social ambiances are at the root of most ties: school, neighbourhood, houses of friends, houses of kin, university, military service, workplace and a few others. It seems therefore that if we want to understand why ethnic concentrations in some cases are particularly high and long-lasting, we should turn to activities and participation in these circles where relationships and social activity are maintained and re-created. 
A crucial point to be stressed in these findings is that the formation of ties are not independent but come in clusters. Any personal tie tends to spring from a previous tie: one's sister, a school friend, etc. takes one to a dance, introduces one to a friend of theirs. A similar point regarding the non-independence of single relationships also emerges when we examine friendships. So although friends often represent their friendships in terms of purely individual affinity, in reality the relationship is not dyadic, but has a strongly configurational aspect (Eve 2002). What people do with friends in fact involves a lot of activity involving others directly or indirectly. For example, much of friends' talk regards other people (gossiping about one's colleagues, giving advice about one's friend's child or husband, mimicking the amusing peculiarities of one's boss); knowledge of these people is thus an important precondition of the friendship. Much of friends' activity together, from playing cards to football, from dinners at the houses of others to Sunday outings in the country, also involves others. One does these things mostly in couples, in families, in groups of friends, and if one particularly crucial member of the configuration drops out (through death or divorce or a quarrel, for example), the individual relationships tend to lapse along with the activities. Friends therefore tend to form, and dissolve, in clusters - which is why an entire cluster of friends often changes after life events like divorce, widowhood, or also engagement or birth of a first child (Milardo 1987; Bidart 1997). The subtraction or addition of one particularly crucial member in one's personal network changes the entire network.

But if we think in terms of ties clustering and following on from one another, this may also explain the over-representation of friends, marriage partners, etc. of the same ethnic group. Attention needs to be directed towards the conditions which support this kind of interaction: for if we do not imagine members of the same ethnic 


\section{Ethnic networks or networks shaped by migration?}

In this relational perspective, how does migration fit in? If we see networks as having a history, relations developing out of previous ties, it is useful to talk of a 'migration process' which systematically shapes social ties, often even in the second generation. Although not everyone takes the beaten track of established migration chains in the classic sense, few migrants are totally without prior contacts (either with locals or conationals) in the place of arrival. For most people these initial ties form the basis for further relations, which have an influence on where one finds work, housing and leisure. In this sense, migration can be seen as a special case of the development of social networks. Anyone who migrates to a different town has to re-organize their network in order to work effectively, to find work, pass leisure time, and so on. Their new networks are shaped by the needs they have, which are not always shared by locals, so it is sometimes easier to find e.g. someone to share childcare with among other migrants. This and the lack of those others around whom, as I have said, talk and activities of friends centre, leads to frequent complaints among migrants about lack of 'integration' and the difficulties of breaking into circles of locals, and a tendency to form ties mostly with other migrants (Stacey 1960; Bozon 1984; Bozon and Thiesse 1986). 
Of course there are many different migration trajectories. So, for example, a highly skilled professional moving to a new town via contacts with other professionals may create a network heavily centred on fellow professionals (Watson 1964). A working class migrant moving via a network of kin and acquaintances may create something more akin to a classic 'ethnic' network: Grieco (1987) gives a fine description of regional migration to a steelworks creating this kind of pattern. I am not implying, therefore, that all forms of migration bring social disadvantage. Indeed, since changing towns is often associated with career moves, and shifts to areas which have more high status jobs, there is often a positive association between occupational status and migration (Blum, De La Gorce and Thélot 1985; Fielding 1995). What I am arguing is that migration has systematic effects on social networks, and that people shape many aspects of their lives in the new location within and through these networks, with effects also on their children.

In any case, the sociological aspects of internal migration seem to deserve more consideration than they have usually received, for internal migration seems a crucial case, able to provide evidence where the kind of network mechanisms I have discussed are in play, but not those of citizenship, and where the significance of cultural differences is often debatable.

Second generation disadvantage produced by internal migration

For this reason, in order to pursue my theoretical argument as to the causes of separation and 'integration' of migrants and their children, it seems worth discussing one case in detail. I will draw on a study of social mobility and stratification in the city of Turin (in Piedmont, north-west Italy) (Bianco 2001). In this case internal 
migration had long-term effects on the stratification system which are reminiscent of the kind of incomplete integration often cited in discussion of ethnic inequalities, and some indications of a degree of social separation (e.g. in marriage partners) reminiscent of the patterns Gordon described. Yet without marked differences in 'culture of origin', and without an evident play of ethnic identity or discrimination. I will first describe the inequalities and then argue that they are linked to network mechanisms.

In the 1950s, '60s and early '70s, Turin was a major centre of internal migration and when the survey $(\mathrm{N}=992)$ was carried out in 1999, a large part of the workforce was of migrant 'origins', especially from the South of Italy but also from the Veneto region and elsewhere. The age range chosen (41-45 - to have people established in an occupational career, but homogeneous in terms of cohort experience) meant that the original immigrants to the city were not included: our 'Southern-origin' interviewees are in fact a 'second generation' (23 per cent of our 'Southerners' were born in the city) or 'one and a half generation', the children of the migrants of the fifties and sixties either born in Turin or arriving as children or adolescents.

Turin's class structure is clearly split along regional-origin lines. Looking at things from the point of view of the composition of different social classes, we can say that (in this age group) three quarters of the working class is of 'Southern origin'. (Our data did not include non-Italians, who were not numerous at the time in the population registry used for the sample, but now foreigners would of course also be very prominent among manual workers, and are rapidly replacing their internal migrant predecessors.) Vice versa, Southerners were badly under-represented in the upper middle class, which is heavily Piedmontese. Looking at things from the point 
of view of the destinations of individuals (Table 1), few 'Piedmontese born-andbreds' of this generation are manual workers (just 9 per cent), whereas a third of those with Southern 'origins' are. At the opposite end of the social scale, 30 per cent of the children of Piedmontese are in established professions and managerial jobs, as against 10 per cent of the children of Southerners. Other features familiar from many cases of stratification patterns linked to international migration are also present, such as a slight over-representation in self-employment; and a higher number of housewives.

\section{TABLE 1 ABOUT HERE}

This major cleavage in occupational position is partly explicable on standard sociological assumptions, for 'Southerners' were more likely to have parents with low occupational and educational status. In fact, they were twice as likely to have had a father as a manual worker, and nearly twice as likely to have a father with only elementary education. Nonetheless, large differences remain between our 'second generation Southern' and 'Piedmontese' interviewees even when we keep class and education of parents constant. For example, if we restrict the focus to those Piedmontese and Southerners who had fathers-in-manual-jobs-with-elementaryschooling ( $\mathrm{n}=173$ Piedmontese and 331 Southerners), the effect of 'regional origins' is still clear. For even in this sub-group, 15 per cent of our 'Piedmontese' interviewees had achieved substantial social mobility and had managerial or professional jobs, whereas only a miserable 3 per cent of their Southern equivalents had done so. Vice versa, nearly half (46 per cent) of these Southern-origin 
interviewees were themselves manual workers like their fathers, as against just 16 per cent of the children of Piedmontese-manual-workers-with-minimum-schooling.

How did 'regional origin' work its effects? As with most social mobility research, the largest effect passes through schooling. In fact, among our Piedmontese interviewees 85 per cent had a high school diploma or university degree, as against 45 per cent of the Southerners. Logistic regression confirms the strong effect of 'region of origin' on school diploma independently of the classical sociological variables of class of origin or parents' education (see Ceravolo, Eve and Meraviglia 2001, section 2). In terms of log likelihood the effect of father's place of birth on our interviewees' school level is almost as strong as the effect of father's class.

It is important to note that, in conformity with the interpretation proposed here which stresses the effects of geographical migration in itself, there are big differences according to the phase of families' migration trajectory. So for example whereas only 39 per cent of the children of Southerners who arrived as children or young people obtained a diploma or degree, 68 per cent of those born in Turin did not as high as the quota for children of Piedmontese locals (85 per cent), but much higher than that of those born in the South (see Table 2).

\section{TABLE 2 ABOUT HERE}

It is also clear that there are effects connected to the rhythms peculiar to migrants and their families (ibid, sec. 3): 'Southern' children who did at least some primary school in Turin have better educational certificates than those who arrived during secondary school. And those who were born in Turin better still. In other words, it seems probable that the disruption caused by changing school, and the 
financial problems migrant families often had in their earlier years, may have influenced school performance and/or the decision to leave school early. Similar effects of families' moves on school careers (and networks) have been noted in other contexts (Hagan, MacMillan and Wheaton 1996; Myers 1999), once again varying with age at migration. Such results seem worth citing in the present context of conceptualizing the mechanisms underlying 'the migration process' as such, independent of citizenship.

The occupational disadvantage of this 'second generation of regional migration' is not entirely due to school. For education certificates seem to produce slightly less 'profit' occupationally for Southerners compared with locals. So if we measure occupational position on a scale of occupational prestige (DESC, a widelyused Italian scale, with a range of scores in our case from 14.88 to 90.20), Piedmontese interviewees with a university degree score 6 points higher on average than graduate 'Southerners', while Piedmontese with a high school certificate score 7 points higher than Southern-origin interviewees with the same certificate. The regression model I have referred to also produces a small (not statistically significant) direct effect for regional origin (independent of that passing through schooling) in terms of chances of moving into the middle class (ibid, sec. 2).

Networks leading to different trajectories

The results I have cited - added to others summarized below - show that certain kinds of internal migration have long-lasting effects on patterns of social stratification, suggesting the feasibility of interpreting data in terms of migration processes. Unfortunately, the survey, not originally designed as a study of migration, 
does not contain detailed migration histories. Nonetheless, as I have indicated, there is indirect evidence of the effects of the length of time a family has been established in the place of arrival, and of the way the timing of migration combines with the phase of a child's school career. It is also pertinent in this context to compare the education and occupational mobility of a previous wave of working class migration to Turin coming from the Veneto region. The 'Venetian origin' interviewees have an intermediate educational and occupational profile between our 'locals' (Piedmontese origin) and our 'Southern origin' interviewees. In fact fewer Veneto-origin interviewees than Southerners are in manual or secretarial jobs, but compared with the Piedmontese-origin interviewees they are much less likely to be managers or in the established professions. In other words, they have a middling profile, similar to that of Southerners-born-in-Turin. Veneto-origin families arrived a few years earlier on average than families from the South: it is not necessary to imagine any necessary linear relationship between date of a family's arrival and educational and occupational success in order to see that such data adds substance to the idea of a local class structure systematically shaped by the mechanisms of migration.

Other research on Turin also indicates that regional origin plays a large part in the stratification structure in Turin. For example, recent research into residents of public housing (Olagnero and Negri 2002) found that no less than 70 per cent of household heads were born in the South. If we add those born in the Veneto, and people born in Turin but of Southern or Venetian parents, plus foreign immigrants, it is clear that public housing in Turin is inhabited almost totally by persons with a migration background of some kind, indicating the importance of the link between migration and economic vulnerability and housing difficulties. Another recent survey on the occupational destinations of two cohorts of people with high school diploma 
and nothing higher (thus holding education constant) found that the children of migrants from the South were only half as likely as the children of Piedmontese to become managers or professionals (Bianco and Ceravolo 2005). Most of this effect is due to differences in class origins, but the existence of such a major difference even among people with the same educational level shows once again how much regional origin overlaps with class and enters into the stratification system of the Turin metropolitan area.

Is Turin peculiar? As Bagnasco (1986) has shown, Turin - dominated for many years by the Fiat auto company - had a much more 'Fordist' occupational structure than other Italian cities. Another large city drawing in large numbers of migrants during the post-war decades such as Milan had a more diversified economy and occupational structure, and it is sometimes suggested that the position of migrants in Milan was different ${ }^{3}$. However, data for northern Italy as a whole, examined by Impicciatore and Dalla Zuanna (2006), gives many similar results to ours, in particular regarding marked educational disadvantage among the children of migrants, especially those moving with their families as children or adolescents. This suggests that the mechanisms in play were quite widespread. In any case it is not my aim to argue that Turin is necessarily the same as all other places in Italy or elsewhere; the interest of the material for me is that it suggests the operation of certain mechanisms not linked to ethnicity as this is normally defined.

So let us examine the mechanisms which may have been in play. The 'immigrants' and their children were obviously all Italians and so did not suffer from the various problems stemming from lack of citizenship. Nor can language problems be evoked; although many of their parents no doubt spoke dialect at home (as did 
many of the Piedmontese parents), our interviewees had a mainly passive knowledge of dialect: their first language was undoubtedly Italian.

How about the other factors often proposed to explain the disadvantage at school or in the labour market among a 'second generation' in the case of international migration? The differences in level of development between North and South Italy are, of course, well known abroad and often (perhaps too often) used as a key to interpretation. Can we imagine cultural differences as explaining the divergence in life chances? The survey contains no information on culture; however, we should be cautious about imagining that the children of the immigrants from the South were brought up in some sort of stereotypical Southern culture. Many of the parents of our interviewees came from urban areas in the South, and 'deep rural' origins among the parents of our 'Southerners' may not have been significantly more common than for interviewees growing up in Piedmont.

It should also be remembered that the culture of children of migrants is created in large part in the place of arrival, in schools, sports clubs, bars, homes of friends, etc. and cannot simply be read off from parents' region of 'origin'. To the extent that culture is relevant, it would seem more consonant with what is known of Turin to think of a culture created in the housing estates. As mentioned in the first section of this article, with regard to the legitimacy of assuming that members of an ethnic group share distinctive cultural characteristics, it does not seem fruitful to separate the analysis of culture from the analysis of the actual local groups who create shared languages, attitudes, expectations (Cuche 2004). It is significant in this context, that the term 'Southerner' used as a social category by actors and commentators is a new one (people having previously identified with a particular town or region). Like terms such as Maghrébin, Beur or Asian, meridionale as a 
social label is a creation of immigration: before the years of mass regional migration it was used in specialist academic contexts but not in general speech to identify people and certainly not a label people identified with. Previous to mass migration, people from the South of Italy thought of themselves as Sicilians, Neapolitans, etc.; it was the labelling of Northern locals, and the fact of growing up on estates with others from a variety of Southern towns and regions, in a social destiny partially separated from 'Northerners' or 'Piedmontese', which gave the term meaning as a social category.

Can prejudice and discrimination explain the patterns in school performance or occupational career I have described? Once again, we cannot directly dismiss this since we do not have information in the survey. However, it does not seem plausible prima facie: for while the first generation of migrants did meet prejudice (Fofi 1964 gives examples of unwillingness to rent flats to Southerners in the 1950s in Turin, as do Alasia and Montaldi 1960 in Milan, and both mention derogatory references in conversation), this was certainly much less marked for the second generation. It is significant that there has never been discussion of discrimination against descendants of Southern migrants either in the sociological literature or in media discussion: the 'second generation' I am talking about is a category emerging out of our research results, not a 'social problem' recognized in public debate.

Let us look, therefore, at networks. Explanations of how the general population finds jobs have often made use of networks, Granovetter's classic (1974) study giving rise to many others. As our survey collected particularly detailed information on the sources of information used to find first job and current job, we know that around three quarters ${ }^{4}$ of all interviewees (with no significant differences by regional origin) made use of introductions and (more commonly) information 
received at some stage of the process of finding their first job. It is local ties which predominate: family are crucial, but not always directly, for often it is the contacts kin have who provide the information, e.g. people known in the neighbourhood, friends of an elder brother. This implies the importance of the ambiences in which such information circulated - giving access to some jobs, but not others. Since migrant kin mostly worked in 'typical immigrant' niches such as building, unskilled work in factories and services, self-employment in restaurants and shops, information mainly regarded these areas. Blackburn and Prandy's (1979) view of workers having extremely selective knowledge of labour market opportunities seems fully confirmed. The phrase 'integration into the labour market' seem appropriate here too, not only given the role of personal relations as sources of information and help, but also due to the impression that there is a process at issue - passing from one social ambiance to another (no doubt acquiring tacit skills enabling one to function effectively in a particular context).

The very abundance of information leading to jobs must have made it tempting for young people in migrant families to leave school early, and for parents (often with tight family budgets) to encourage them to do so. It seems likely that in these ambiences where migrants and their children lived and worked and socialized, notions were formed - adapted to what were the most visible opportunities in the labour market. In this way, no doubt relatives, friends and neighbours affected notions of what was a feasible career. No doubt the fact that school friends left for work influenced the decisions of others remaining in a depleted class. I suggest that in the neighborhoods where Southern families were concentrated in Turin, the conventions of what was normal regarding the proper time to leave school were 
different even from those in neighbourhoods and schools where working-class families were mainly of Piedmontese origin.

Social networks do seem to have been fairly clearly separated on regional lines at the time our interviewees were growing up, and this had effects on many aspects of life. One index of this is the degree of endogamy found in the survey: 65 per cent of married Piedmontese-origin interviewees were married to a 'Piedmontese' spouse, while 69 per cent of 'Southern' origin interviewees were married to someone coming from the South (percentages are still higher among manual workers). These relatively high rates of 'endogamy' probably just reflect the ambiances, like neighbourhood, holidays and school, where spouses are found. Our interviewees grew up in a city which was in large part rebuilt around immigration, for Turin increased in population by 63 per cent from 700000 to 1170000 between 1951 and 1969, and this led in the 1960s and '70s to the building of entire new neighbourhoods - creating what a number of commentators (Fofi 1964; Olagnero 1985; Lerner 1988) pointed out was an urban structure clearly segregated along regional-origin lines. Many of our 'Southern' interviewees must have grown up in neighbourhoods inhabited almost solely by other Southerners. As one woman who arrived as a child remembers, describing the friendships she formed in her youth, 'they were mostly Southerners, because in [the street she grew up in] ninety per cent were Southerners. You might say it was a ghetto!' (Badino 2008, p. 134).

It is, of course, common for mass migration to expand a city radically, in the process creating predominantly migrant neighbourhoods. It is also usual, of course, for school attended to be linked to parents' residence (except for those parents who might decide to give as their official address that of a relative in a better area something easier for Piedmontese parents because they had more relatives living in 
different areas and with knowledge of the reputation of particular schools). It is worth remembering in this context that 'ethnic' concentrations in schools may be even higher than in the surrounding neighbourhood. Foner (2000, p.193) refers to an entire school district in 1905 New York as 95 per cent Jewish. This is an extreme case but migration often creates high concentrations. Mass migration waves are by their nature episodic: most flows from a particular region only last a few years in full spate. At the same time, since most migration waves are composed primarily of young adults who start or continue a family a few years after migration, migration waves are usually associated with large numbers of children in schools. The two factors together produce a bunching of children from the same 'origins' going into the same school classes in the same few years. In addition, families themselves often further accentuate concentration. Immigrant parents pressed for time may prefer a child to go where a brother or sister already goes in order to simplify logistical problems or because they think it is safer or more comforting for a younger brother or sister. Even if the sibling in question has left the school, the parent may feel comfortable knowing the teachers. If a school achieves a poor reputation, the flight of local parents accentuates concentration. Concentration does not inevitably produce disadvantage, but in many cases it does (see Van Zanten 2001 for a convincing account of the various mechanisms which create segregation and disadvantage). In any case, concentration inevitably strongly influences the pattern of children's social relations and the youth culture they acquire.

It seems justifiable to talk, in the Turin case as elsewhere, of mass migration systematically creating local ambiances of particular kinds. It seems plausible to hypothesize that these generate specific work opportunities, 
expectations, and various aspects of 'culture' (in the concrete sense I have indicated) which may have effects on social inequalities.

\section{Ethnic inequalities and migration inequalities}

Attempts to explain different paths of occupational mobility and school success by reference to the local environment of the neighbourhood and friends are certainly not new: my analysis obviously fits into the tradition of research which gives importance to factors like segregation of residential areas and schools. However, I believe it is useful to set these factors in a general framework whereby people form social relationships, in order to clarify the mechanisms in play. In particular, when we are concerned with what are termed a little too unproblematically 'ethnic networks', it may be helpful to insist on the need for a sociological explanation of particular ties, and an account of how they emerge from preceding ties.

In the first part of this article I suggested that network mechanisms similar to those operating in the general population could account for a large part of the intraethnic concentrations of personal ties like friendship and marriage reported by many studies in Gordon's time and since. I argued that concentrations of ethnic ties cannot simply be assumed as natural but should stimulate enquiry into their sociological roots (Eve 1998, 2002). There is of course a great deal of rich work on ethnic networks, but little systematic investigation of how such ties were formed. To the extent that the question is explicitly raised, reference may be made to the citizenship handicaps and difficulties of being a member of a stigmatized group which make 'ethnic solidarity' necessary, and contacts with the majority difficult. Yet it is often difficult to demonstrate that ethnic concentrations and ethnic inequalities really are 
driven by ethnic identities. Cases of internal migration like that I have cited seem useful for exploring the mechanisms at issue. Notwithstanding the obvious differences between international and internal migrants, some important features are similar. The time needed for 'integration into the labour market' - a gradual process of constructing knowledge and contacts, often imposes distinctive rhythms on work careers and on family budgets: migrants' timing of life events are probably specific. These rhythms and constraints may have effects also on children's careers, the attractiveness of education rather than work, knowledge of 'the labour market'. At the same time migration systematically re-constitutes family and kin relationships, relations with neighbours, relations in schools. There are also institutional factors associated with most large-scale migrations - for example, the construction of entire new neighbourhoods. It seems worth focusing attention on these areas where the migration process creates new ties - often, but not always, with people with a similar migration trajectory.

MICHAEL EVE is professore associato in the social sciences faculty, Università del Piemonte orientale.

ADDRESS: Dipartimento di ricerca sociale, via Cavour 84, Alessandria (AL), 15100 Italy. Email: michael.eve@sp.unipmn.it 


\title{
References
}

\author{
ALASIA, FRANCO, MONTALDI, DANILO 1960 Milano, Corea, Milan: Feltrinelli \\ BADINO, ANNA 2008 Tutte a casa? Donne tra migrazione e lavoro nella Torino \\ degli anni Sessanta, Rome: Viella \\ BAGNASCO, ARNALDO 1986 Torino: un profilo sociologico, Turin: Einaudi \\ BARBIERI, PAOLO, 1997 'Il tesoro nascosto. La mappa del capitale sociale in \\ un'area metropolitana, Rassegna italiana di sociologia, 3 \\ BIANCO, MARIA LUISA, (ed.) 2001 L'Italia delle diseguaglianze, Roma: Carocci \\ BIANCO, MARIA LUISA and CERAVOLO FLAVIO 2005 I diplomati dell'area \\ metropolitana torinese, Rapporto di ricerca, Turin: Fondazione Agnelli \\ BLACKBURN, ROBERT and PRANDY, KENNETH, 1979 The Working Class in \\ the Labour Market, London: MacMillan
}

BLUM, A., DE LA GORCE, G. and THELOT, C. 1985 'Mobilité sociale et mobilité géographique', Population, 3

BOZON, MICHEL 1984 Vie quotidienne et rapports sociaux dans une petite ville de province, Lyon: Presses universitaires de Lyon BOZON, MICHEL and HERAN, FRANCOIS 1989 'Finding a spouse: A survey of how French couples meet', Population: English Selection, 1, pp. 91-122 - 2006 La formation du couple, Paris: La découverte BOZON, MICHEL and THIESSE, ANNE-MARIE 1986 La terre promue. Gens $d u$ pays et nouveaux habitants dans les villages du Valois, Paris: Fondation Royaumont 
CERAVOLO, FLAVIO, EVE, MICHAEL and MERAVIGLIA, CINZIA 2001

'Migrazioni e integrazione sociale: un percorso a stadi', in Maria Luisa Bianco (ed.) 2001, pp. 83-116

CUCHE, DENYS 2004 La notion de culture dans les sciences sociales, Paris : La découverte

EVE, MICHAEL 1998 'Qui se ressemble s'assemble?' in M. Gribaudi, (ed.) Espaces, temporalités, stratifications, Paris: Editions de l'EHESS, pp. 43-69

- 2002 'Is friendship a sociological topic?' Archives européennes de sociologie, 3, pp. 386-409

FIELDING, TONY 1995 'Migration and middle-class formation in England and Wales, 1981-91', in T. Butler and M. Savage (eds), Social Change and the Middle Classes, London: UCL Press

FOFI, GOFFREDO 1964 L'immigrazione meridionale a Torino, Milan: Feltrinelli FONER, NANCY 2000 From Ellis Island to JFK, New Haven: Yale University Press

GORDON, MILTON 1964 Assimilation in American Life, New York: Oxford University Press

GRIECO, MARGARET 1987 Keeping it in the Family. Social Networks and Employment Chance, London: Tavistock

HAGAN, JOHN, MACMILLAN, ROSS and WHEATON, BLAIR 1996 'New kid in town', American Sociological Review, vol. 61, no. 3, pp. 368-385 IMPICCIATORE, ROBERTO and DALLA ZUANNA, GIANPIERO 2006 'A difficult social mobility. Internal migrations and educational attainments of migrants from Southern to Northern Italy', Genus, 63 (3-4), pp.155-201 
LEPOUTRE, DAVID 1997 Coeur de banlieue. Codes, rites et langages, Paris: Odile Jacob

LERNER, GAD 1988 Operai, Milan: Feltrinelli

MYERS, SCOTT 1999 'Childhood migration and social integration in adulthood', Journal of Marriage and the Family, vol.61, no.3, pp.774-89

NEGRI, NICOLA 1982 'I nuovi torinesi: immigrazione, mobilità e struttura sociale' in Guido Martinotti (ed.) La città difficile, Turin: Franco Angeli, pp. 53-179 NOIRIEL, GERARD 1992 Population, immigration et identité nationale en France, Paris: Hachette OLAGNERO, MANUELA 1985 'La gente di Torino', in Enzo Marra (ed.) Per un atlante sociale della città, Milan: Franco Angeli, pp. 309-405

OLAGNERO, MANUELA and NEGRI, NICOLA 2002, Base dati residenti degli alloggi Turin: ATC SCHNAPPER, DOMINIQUE 1991 La France de l'intégration. Sociologie de la nation en 1990, Paris: Gallimard STACEY, MARGARET 1960 Tradition and Change. A Study of Banbury, London: Oxford University Press VAN ZANTEN, AGNES 2001, L'école de la péripherie. Scolarité et ségrégation en banlieue, Paris: PUF WATSON, W. 1964, 'Social class in industrial communities' in Gluckman, M., Devons, E., Closed Systems, Open Minds: the limits of naïvety in social anthropology, Edinburgh: Oliver and Boyd WHYTE, WILLIAM FOOTE 1943 Street Corner Society : The Social Structure of an Italian Slum, Chicago: Chicago University Press 


\begin{tabular}{|l|c|c|c|c|c|}
\hline & Managers, & White & Self- & Manual & $n$ \\
& & collar, & employed & workers & \\
& & semi- & & & \\
\hline Children of & 29.8 & 54.1 & 7.1 & 9.0 & 459 \\
Piedmontese & & & & & \\
\hline Children of & 10.2 & 44.0 & 12.5 & 33.3 & 440 \\
Southerners & & & & & \\
\hline
\end{tabular}

Table 1: Class of destination in Turin by regional origin (percentages) 


\begin{tabular}{|l|c|c|c|c|}
\hline & $\begin{array}{c}\text { Minimum or low } \\
\text { vocational }\end{array}$ & $\begin{array}{c}\text { High school } \\
\text { diploma }\end{array}$ & University & $n$ \\
\hline Piedmontese & 15.1 & 48.3 & 36.7 & 431 \\
\hline Born in Turin, father & 31.6 & 49.5 & 18.9 & 95 \\
born in South & 60.9 & 29.4 & 9.8 & 327 \\
\hline Born in South & & & & \\
\hline
\end{tabular}

Table 2: Educational certificates of Turin interviewees by 'regional origin' and birthplace (percentages) 


\section{Notes}

${ }^{1}$ I agree with those like Schnapper (1991) or Noiriel (1992) who have argued that there are important questions of the 'sociology of the nation' at issue: I simply want to point out there are also other more 'micro' or 'meso' level questions which have been neglected.

${ }^{2}$ This stress on local social context and specifically relational logic, does not imply that there is some 'social' realm totally independent of 'cultural' criteria: cultural competence is fundamental to the creation of almost all social ties (we need only think how important talk is in nearly all social relationships). But only rarely can the competence required in a particular relationship be read off from ethnic identity. If, for example, we consider the 'codes, rites and language' which form the object of Lepoutre's analysis of the adolescents of his cité, we find a culture which is markedly specific, and rather isolated, a 'street culture' which certainly conditions the social relations formed with others (both inside the estate and outside). But to imagine analysing it in terms of the places of birth of the parents of the boys concerned (from Senegal to metropolitan France, Algeria to Mauritius) would be unthinkable. Culture is continuously created and re-created in the lives of the people concerned. In Lepoutre's case, informal activities on the housing estate bring children together; hence the street culture they create together (and inherit from older boys) is formed on an estate basis. In other cases, configurations place people of the same 'national origins' together, and the language, rites and codes created are likely to have more of an 'ethnic' tonality (although likely to be very different from that of parents). In short, I am not underestimating 'culture' and its importance in founding social ties, but rather stressing that culture is continually created and re-created in conversation and interaction with others. For this reason, it is not enough to use an ethnic label to assume the existence or lack of ease of cultural communication. We need empirical data.

${ }^{3}$ However, we should distinguish between the city of Milan itself (a relatively small area, with a very distinctive occupational structure) and the metropolitan area as a whole: most industry is in fact outside the city boundaries, as are most homogeneously working class residential areas. In addition, it 
should also be noted that migration to Milan from the South started earlier than in Turin, being quite significant even in the 1930s.

${ }^{4}$ The high percentage is linked to the detailed nature of the questioning in the survey rather than to an Italian peculiarity. 


\begin{tabular}{|l|c|c|c|c|c|}
\hline & $\begin{array}{c}\text { Managers, } \\
\text { professions }\end{array}$ & $\begin{array}{c}\text { White collar, } \\
\text { semi-profess. }\end{array}$ & $\begin{array}{c}\text { Self- } \\
\text { employed }\end{array}$ & $\begin{array}{c}\text { Manual } \\
\text { workers }\end{array}$ & $n$ \\
\hline $\begin{array}{l}\text { Children of } \\
\text { Piedmontese }\end{array}$ & 29.8 & 54.1 & 7.1 & 9.0 & 459 \\
\hline $\begin{array}{l}\text { Children of } \\
\text { Southerners }\end{array}$ & 10.2 & 44.0 & 12.5 & 33.3 & 440 \\
\hline
\end{tabular}

Table 1: Class of destination in Turin by regional origin (percentages) 


\begin{tabular}{|l|c|c|c|c|}
\hline & $\begin{array}{c}\text { Minimum or low } \\
\text { vocational }\end{array}$ & $\begin{array}{c}\text { High school } \\
\text { diploma }\end{array}$ & $\begin{array}{c}\text { University } \\
\text { degree }\end{array}$ & $n$ \\
\hline Piedmontese & 15.1 & 48.3 & 36.7 & 431 \\
\hline $\begin{array}{l}\text { Born in Turin, father born } \\
\text { in South }\end{array}$ & 31.6 & 49.5 & 18.9 & 95 \\
\hline Born in South & 60.9 & 29.4 & 9.8 & 327 \\
\hline
\end{tabular}

Table 2: Educational certificates of Turin interviewees by 'regional origin' and birthplace (percentages) 